\title{
Tomato seedling growth response to different water sources and a substrate partially replaced with dewatered aquaculture effluent
}

\author{
Jason J. Danaher ${ }^{1} \cdot$ Jeremy M. Pickens $^{2} \cdot$ Jeffrey L. Sibley $^{2} \cdot$ Jesse A. Chappell $^{3}$. \\ Terrill R. Hanson ${ }^{3}$ Claude E. Boyd ${ }^{3}$
}

Received: 5 June 2015/ Accepted: 5 January 2016/Published online: 22 January 2016

(c) The Author(s) 2016. This article is published with open access at Springerlink.com

\begin{abstract}
Purpose The experiment was performed to determine the effect a commercial potting mix partially replaced with dewatered aquaculture effluent had on tomato transplant growth.

Methods The experiment was designed as a $2 \times 3$ factorial and evaluated two water sources (water-soluble, inorganic fertilizer or municipal water) and three soilless substrates with 0,5 or $10 \%$ dewatered aquaculture effluent (v/v) on substrate properties and tomato (Solanum lycopersicum Mill. 'Bolseno') transplant growth. The layout was a completely randomized design with twelve single-pot replications for each treatment.

Results There was a substrate and water interaction affecting plant height, leaf dry matter (LDM), stem dry matter, root dry matter (RDM), and total dry matter (TDM). Tomato plants watered with inorganic fertilizer and grown in substrates replaced with 0 and $5 \%$ dewatered aquaculture effluent had greater LDM, RDM, and TDM compared to plants watered with municipal water. However, tomato plant growth in substrate partially replaced with $10 \%$ dewatered aquaculture effluent was similar irrespective of water source.

Conclusion Substrates incorporated with $10 \%$ aquaculture effluent provided optimal physical and chemical
\end{abstract}

Jason J. Danaher

jason.danaher@pentair.com

1 Pentair Aquatic Ecosystems, 2395 Apopka Boulevard, Apopka, FL 32703, USA

2 Department of Horticulture, Auburn University, 101 Funchess Hall, Auburn, AL 36849, USA

3 School of Fisheries, Aquaculture and Aquatic Sciences, 203 Swingle Hall, Auburn, AL 36849, USA properties along with sufficient nutrients for tomato transplants without the need for commercial, inorganic fertilizer.

Keywords Waste management - Aquaculture - Tomato · Transplants $\cdot$ Substrate $\cdot$ Integrated systems
Abbreviations
AE Aquaculture effluent
F3B Fafard 3B potting mix
EC Electrical conductivity
NPK Nitrogen, phosphorus and potassium
PSD Particle size distribution
TP Total porosity
CC Container capacity
AS Air space
BD Bulk density
DAP Days after potting

\section{Introduction}

Aquaculture is one of the fastest growing sectors of agriculture. A decline in capture fisheries, coupled with a strong consumer-driven demand for aquaculture products, has resulted in the adoption of intensive fish production facilities. Aquaculture farms have intensified and require solutions to manage discharged wastes. Recirculating aquaculture systems (RAS) have incorporated water treatment technology to manage toxic dissolved nutrients and solid waste. This technology allows the producer to maximize production per unit area and reuse limited freshwater resources. The RAS technology is used to produce popular 
food species like Nile tilapia (Oreochromis niloticus; Azim and Little 2008). To ensure water quality remains optimal for the fish, a RAS discharges concentrated organic matter and dissolved wastes daily. Even though the point of discharge is well defined, the concentrated organic matter and dissolved nutrients are still a liability for the producer. Effluent leaving production facilities is regulated by environmental agencies (Ebeling et al. 2005). Capturing and treating discharged wastes on-site would help intensive aquaculture production facilities address waste management regulations and prevent eutrophication.

While intensive aquaculture facilities are examining technologies to capture and treat discharged effluent, the horticulture industry is evaluating alternative soilless substrates for vegetable seedling production. Sphagnum peatmoss remains extremely important to the US greenhouse industry and is used as a primary component for greenhouse grown plants because of its desirable physical and chemical properties. Some regions of peatlands around the world face pressure from industrial and agricultural interests. These environmental impacts of peat harvesting have been debated in North America and Europe for a number of years. As a result, environmental agencies along with the peat industry have launched conservation efforts. In addition, transportation costs have escalated to ship peat affecting profitability for horticulture producers; therefore, the horticulture industry has evaluated alternative substrates to substitute peat for tomato seedling production. Alternative substrates investigated were coconut coir (Arenas et al. 2002), wood fiber (Gruda and Schnitzler 2004), rice hulls (Evans and Gachukia 2004), spent mushroom waste (Eudoxie and Alexander 2011), swine waste (Ribeiro et al. 2007), municipal solid waste (Herrera et al. 2008; Kasmi et al. 2012), pulp mill sludge (Levy and Taylor 2003), vermicompost (Atiyeh et al. 2000; Bachman and Metzger 2008) and green waste composts (Ceglie et al. 2011). However, few experiments investigated solid matter in aquaculture effluent as a substrate amendment for vegetable seedlings.

Boyd and Tucker (1998) reported only 25 to $30 \%$ of the nitrogen input to an aquaculture production system is assimilated in the final fish biomass. Integrated agriculture systems could help improve use of farm inputs, like fish feed. Nitrogen (Rakocy et al. 2003) and phosphorus (Adler et al. 2003) concentrations in treated aquaculture effluent are suitable for plant production. Palada et al. (1999) reported field grown bell peppers (Capsicum annuum L.) provided aquaculture effluent grew well compared to other fertilizers evaluated. Nair (2006) reported coleus (Coleus $\times$ hybridus Blume) grew well in substrates containing vermicomposted aquaculture effluent. Danaher et al. (2011) reported composted aquaculture effluent was a good alternative substrate for tomato (Solanum lycopersicum). Tomato transplants also responded positively to substrate partially replaced with dewatered aquaculture effluent at 5-15\% container volume (Danaher et al. 2014). Pantanella et al. (2011) reported composted aquaculture effluent was a suitable substrate replacement for containerized lettuce (Lactuca sativa L.) and basil (Ocimum basilicam L.) production.

The objective of this experiment was to evaluate tomato plant growth in response to different combinations of substrate and water sources and determine if dewatered aquaculture effluent could partially replace a commercial substrate while providing adequate nutrients for plant growth.

\section{Materials and methods}

The discharged aquaculture effluent (AE) was collected from a $100-\mathrm{m}^{3}$ intensive, freshwater RAS producing Nile tilapia. A $3.5 \mathrm{~m} \times 1.5 \mathrm{~m}$ woven geotextile bag (U.S. Fabrics, Inc., Cincinnati, $\mathrm{OH}$ ) and polyacrylamide polymer Hyperfloc CE 854 (Hychem, Inc., Tampa, FL) were used to dewater discharged AE. After repeated fillings, the bag was allowed to dewater and was cut open to remove the solids. Solids were allowed to air-dry and then further processed with a hammer mill (Model 30; C.S. Bell Co., Tiffin, $\mathrm{OH})$ to pass through $0.635-\mathrm{cm}$ screen. Two substrates were prepared prior to the experiment by substituting (v/v) Fafard 3B (F3B) mix (Conrad Fafard, Inc., Agawam, MA) with 5 or $10 \%$ AE. The F3B mix consisted of Canadian sphagnum peat moss $(50 \%)$, processed pine bark, perlite, vermiculite, starter nutrients, wetting agent and dolomitic limestone. A composite sample of the F3B and $\mathrm{AE}$ was taken and analyzed at the Auburn University Soils Laboratory for chemical properties (Table 1). Saturated media method was used to extract soluble salts and elements were determined simultaneously by inductively coupled plasma atomic emission spectrometry using a radial spectrometer (Vista-MPX; Varian Inc., Palo Alto, CA). The substrate $\mathrm{pH}$ was determined using a bench-top meter (Fisher Accumet Model 50, Fisher Scientific). Inorganic nitrogen was analyzed according to Sims et al. (1995) and total nitrogen and carbon according to methods described by Kirsten (1979).

Three replicates of each substrate were used to determine total porosity (TP), container capacity (CC), airspace (AS), and bulk density (BD) following procedures described by Bilderback et al. (1982). The BD $\left(\mathrm{g} \mathrm{cm}^{-3}\right)$ was determined from $347.5 \mathrm{~cm}^{-3}$ substrate samples dried in a forced air oven at $70{ }^{\circ} \mathrm{C}$ for $72 \mathrm{~h}$. Physical properties of substrates are presented in Table 2. Four replicates of each substrate were analyzed for particle size distribution (PSD) by passing a $100 \mathrm{~g}$ sample through 9.5, 6.35, 3.35, 2.36, 
Table 1 Chemical properties from composite sample of Fafard 3B mix (F3B) and dewatered aquaculture effluent (AE) used as soilless substrates in the tomato experiment

\begin{tabular}{|c|c|c|c|c|c|c|c|c|c|c|c|c|c|c|}
\hline & \multicolumn{14}{|c|}{ Parameter $^{\mathrm{Z}}$} \\
\hline & $\mathrm{pH}$ & EC & $\mathrm{NH}_{4}-\mathrm{N}$ & $\mathrm{NO}_{3}-\mathrm{N}$ & $\mathrm{Ca}$ & $\mathrm{Mg}$ & $\mathrm{P}$ & K & S & $\mathrm{Na}$ & B & $\mathrm{Fe}$ & $\mathrm{Mn}$ & $\mathrm{Zn}$ \\
\hline F3B & 6.4 & 1.3 & 28.2 & 46.9 & 61.7 & 66.0 & 10.5 & 129.5 & 130.5 & 17.5 & 0.03 & 0.56 & 0.38 & 0.99 \\
\hline $\mathrm{AE}$ & 6.6 & 2.2 & 129.8 & 0.8 & 83.6 & 51.6 & 70.2 & 204.5 & 111.9 & 82.6 & 0.13 & 0.70 & 0.21 & 0.83 \\
\hline
\end{tabular}

$\overline{\mathrm{z}}$ Electrical conductivity (EC), $1 \mathrm{mS} \mathrm{cm}{ }^{-1}=1 \mathrm{mmho} \mathrm{cm}^{-1}$; macronutrients and micronutrients reported as $\mathrm{mg} \mathrm{kg}^{-1}$

Table 2 Physical properties of substrates substituted with different volumes of dewatered aquaculture effluent (AE) to grow tomato seedlings

\begin{tabular}{|c|c|c|c|c|}
\hline Substrate & Total porosity $(\%)^{\mathrm{z}}$ & Container capacity $(\%)^{\mathrm{y}}$ & Air space $(\%)^{\mathrm{x}}$ & Bulk density $\left(\mathrm{g} \mathrm{cm}^{-3}\right)^{\mathrm{w}}$ \\
\hline $0 \% \mathrm{AE}$ & $85.1 \mathrm{a}^{\mathrm{v}}$ & $66.6 \mathrm{a}$ & $18.5 \mathrm{a}$ & $0.17 \mathrm{c}$ \\
\hline $5 \% \mathrm{AE}$ & $83.7 \mathrm{a}$ & $66.0 \mathrm{a}$ & $17.7 \mathrm{a}$ & $0.19 b$ \\
\hline $10 \% \mathrm{AE}$ & $80.5 b$ & $68.1 \mathrm{a}$ & $12.4 \mathrm{a}$ & $0.21 \mathrm{a}$ \\
\hline Sufficiency range ${ }^{w}$ & $50-80$ & $45-65$ & $10-30$ & $0.19-0.70$ \\
\hline
\end{tabular}

${ }^{\mathrm{z}}$ Total porosity is container capacity + air space

${ }^{y}$ Container capacity is (wet weight - oven dry weight)/volume of the sample

${ }^{x}$ Air space is volume of water drained from the sample/volume of the sample

${ }^{\mathrm{w}}$ Bulk density after forced air drying at $105{ }^{\circ} \mathrm{C}$ for $48 \mathrm{~h} ; 1{ }^{\circ} \mathrm{C}=\left(1.8 \times{ }^{\circ} \mathrm{C}\right)+32 ; 1 \mathrm{~g} \mathrm{~cm}^{-3}=0.5780 \mathrm{oz} \mathrm{inch}^{-3}$

${ }^{v}$ Means within columns followed by different letters were significant with Tukey's test $(P<0.05)$

u Sufficiency ranges reported by Yeager et al. (2007)

2.0, 1.4, 1.0, 0.5, and $0.25 \mathrm{~mm}$ sieves with particles passing through the $0.25 \mathrm{~mm}$ sieve collected in a pan. Sieves were shaken for 3 min with a Ro-Tap sieve shaker [278 oscillations/min, 159 taps/min (Ro-Tap RX-29; W.S.Tyler, Mentor, OH)]. The PSD for each substrate is presented in Table 3. The non-destructive Virginia Tech pour-through extraction method (Wright 1986) was used to determine substrate $\mathrm{pH}$ and electrical conductivity (EC) of substrate leachate using a bench-top multiparameter meter (Accumet Excel XL50; Fisher Scientific; Table 4).

The experiment was performed in a double-layer, polyethylene-covered greenhouse at the E.W. Shell Fisheries Center, North Auburn Unit, in Auburn, Alabama from 22 October to 17 November 2012. The trial was designed as a $2 \times 3$ factorial evaluating two water sources (water-soluble, inorganic fertilizer or municipal water) and F3B mix substituted with different amounts $(0$, 5 , or $10 \%$ ) of AE. The experiment was a completely randomized design with twelve single-pot replications for each treatment. Tomato seeds were germinated in a 288-cell flat containing F3B mix and on 22 October, one uniform transplant was transferred into each $473 \mathrm{~cm}^{-3}$ square $(9.84 \mathrm{~cm} \times 8.57 \mathrm{~cm})$ plastic pot (Dillen ${ }^{\text {TM }}$ Products, Middlefield, $\mathrm{OH}$ ) containing the aforementioned substrates when the first true leaves developed. All pots were placed on raised benches and for the first week all pots were watered with municipal water as needed.
Thereafter, pots were watered as needed according to treatment with either municipal water or fertigated, twice weekly, using a Dosatron ${ }^{\circledR}$ (Dosatron International, Inc., Clearwater, FL) injector at $100 \mathrm{mg} \bullet \mathrm{L}^{-1}$ nitrogen with a water-soluble $20 \mathrm{~N}-4.4 \mathrm{P}-16.6 \mathrm{~K}$ fertilizer (SDT Industries, Inc., Winnsboro, LA) containing chelated micronutrients. All treatments were watered until substrate reached saturation (i.e., until water leached from the bottom of the pot). At 25 days after potting (DAP) leaf greenness was quantified for all plants using a chlorophyll meter (SPAD502; Minolta Camera Company, Ramsey, NJ) and taking the average reading of four random leaflets per plant (Table 5). Plant height was measured 26 DAP (Table 5). Stem dry matter (SDM), leaf dry matter (LDM), root dry matter (RDM), and total plant dry matter (TDM) were measured 26 DAP (Table 6). The TDM included cotyledons.

Two-way analysis of variance (ANOVA) was used to determine the main effect of substrate and water on tomato plant growth. If a significant interaction existed $(P \leq 0.05)$, pairwise comparisons on the individual group means within each simple effect were conducted and means were separated using the Bonferroni adjusted $\alpha$-level $(P \leq 0.05)$. If no significant $(P>0.05)$ statistical interaction was identified, the main effects of substrate and water were analyzed separately and means were separated by Tukey's test $(P \leq 0.05)$. 
Table 3 Particle size analysis as percent of sample weight for substrates substituted with different volumes of dewatered aquaculture effluent (AE)

\begin{tabular}{lccc}
\hline & \multicolumn{3}{l}{ Substrate } \\
\cline { 2 - 4 } & $0 \% \mathrm{AE}$ & $5 \% \mathrm{AE}$ & $10 \% \mathrm{AE}$ \\
\hline Sieve opening (mm) & & \\
9.50 & $1.4 \mathrm{a}^{\mathrm{z}}$ & $1.4 \mathrm{a}$ & $1.4 \mathrm{a}$ \\
6.35 & $7.3 \mathrm{a}$ & $5.7 \mathrm{ab}$ & $4.5 \mathrm{~b}$ \\
3.35 & $14.7 \mathrm{a}$ & $13.1 \mathrm{ab}$ & $11.3 \mathrm{~b}$ \\
2.36 & $9.1 \mathrm{~b}$ & $10.3 \mathrm{a}$ & $9.8 \mathrm{ab}$ \\
2.00 & $3.7 \mathrm{c}$ & $4.6 \mathrm{~b}$ & $5.4 \mathrm{a}$ \\
1.40 & $9.8 \mathrm{c}$ & $11.4 \mathrm{~b}$ & $12.8 \mathrm{a}$ \\
1.00 & $12.2 \mathrm{a}$ & $10.9 \mathrm{c}$ & $11.6 \mathrm{~b}$ \\
0.50 & $28.3 \mathrm{a}$ & $20.3 \mathrm{~b}$ & $19.5 \mathrm{~b}$ \\
0.25 & $11.6 \mathrm{~b}$ & $14.2 \mathrm{a}$ & $13.7 \mathrm{a}$ \\
0.11 & $1.9 \mathrm{c}$ & $7.6 \mathrm{~b}$ & $8.9 \mathrm{a}$ \\
0.05 & $0.1 \mathrm{c}$ & $0.5 \mathrm{~b}$ & $1.1 \mathrm{a}$ \\
0.00 & $0.0 \mathrm{a}$ & $0.0 \mathrm{a}$ & $0.0 \mathrm{a}$ \\
Texture & & & \\
Coarse & $23.3 \mathrm{a}$ & $20.2 \mathrm{~b}$ & $17.3 \mathrm{c}$ \\
Medium & $34.8 \mathrm{c}$ & $37.1 \mathrm{~b}$ & $49.5 \mathrm{a}$ \\
Fine & $41.9 \mathrm{a}$ & $42.7 \mathrm{a}$ & $43.2 \mathrm{a}$ \\
\hline
\end{tabular}

Means within rows marked by a different letter were significant with Tukey's test $(P \leq 0.05) ; n=3$

${ }^{\mathrm{y}}$ Coarse $>3.35 \mathrm{~mm}$; $\quad$ medium $\geq 1.00 \mathrm{~mm}$ and $\leq 3.35 \mathrm{~mm}$; fine $<1.00 \mathrm{~mm}$

\section{Results and discussion}

The AS and CC were unaffected by increased proportions of $\mathrm{AE}$ (Table 2); however, the inclusion of $\mathrm{AE}$ at $\geq 5 \%$ container volume resulted in greater substrate BD. Bulk density of soilless substrate typically increases as the amount of animal-based wastes used to amend the substrate increases (Atiyeh et al. 2001). The PSD provides some explanation for the difference in TP and BD among substrates (Table 3). As the amount of AE increased, the percent of coarse-sized particles decreased and the percent of medium-sized particles increased. This redistribution of particle size affected the physical properties of the substrates. Melgar-Ramirez and Pascual-Alex (2010) and Hicklenton et al. (2001) reported container substrate physical properties were influenced by increased levels of compost; nonetheless, the substrate physical properties in the present study were optimal (Yeager et al. 2007).

There was no substrate and water interaction for $\mathrm{pH}$ or EC of container leachate at 4, 19, or 25 DAP (Table 4). The main effect of water did not affect $\mathrm{pH}$ at 4,19 or 25 DAP; but, the main effect of substrate directly affected both substrate leachate $\mathrm{pH}$ and EC values at 4, 19 and 25 DAP. Increased proportions of AE increased leachate $\mathrm{pH}$ at 4 DAP. Tyler et al. (1993) and Marble et al. (2010) also reported elevated $\mathrm{pH}$ of container substrates with increased amounts of composted poultry litter. In addition, MelgarRamirez and Pascual-Alex (2010) also reported a direct relationship between the quantity of vermicompost and substrate $\mathrm{pH}$ of container media. In the present study, the substrate leachate $\mathrm{pH}$ for $\mathrm{AE}$ amended substrates approached optimal ranges by 19 DAP and remained lower than $0 \% \mathrm{AE}$ for the remainder of the experiment.

Proportions of $\geq 5 \% \mathrm{AE}$ increased substrate leachate EC values at 4 DAP (Table 4). The substrate leachate EC value of $10 \% \mathrm{AE}$ remained greater than other substrates at 19 and 25 DAP, but $5 \% \mathrm{AE}$ was similar to $0 \% \mathrm{AE}$ at 19 and 25 DAP (Table 5). Increased substrate leachate EC values observed with $10 \%$ AE may have resulted from the continuous physical breakdown and release of soluble salts.
Table 4 The $\mathrm{pH}$ and electrical conductivity (EC) of substrates substituted with different volumes of dewatered aquaculture effluent (AE) 4, 19, and 25 days after potting (DAP)

\begin{tabular}{|c|c|c|c|c|c|c|}
\hline \multirow[t]{2}{*}{ Main effect } & \multicolumn{3}{|l|}{$\mathrm{pH}$} & \multicolumn{3}{|c|}{$\mathrm{EC}\left(\mathrm{mS} \mathrm{cm} \mathrm{c}^{-1}\right)$} \\
\hline & $4 \mathrm{DAP}^{\mathrm{z}}$ & 19 DAP & 25 DAP & 4 DAP & 19 DAP & 25 DAP \\
\hline \multicolumn{7}{|l|}{ Substrate } \\
\hline $0 \% \mathrm{AE}$ & $6.4 \mathrm{c}$ & $7.1 \mathrm{a}$ & $6.7 \mathrm{a}$ & $1.0 \mathrm{c}$ & $0.3 b$ & $0.2 b$ \\
\hline $5 \% \mathrm{AE}$ & $6.5 b$ & $6.4 \mathrm{~b}$ & $6.4 \mathrm{~b}$ & $1.6 \mathrm{a}$ & $1.0 \mathrm{~b}$ & $0.4 \mathrm{~b}$ \\
\hline $10 \% \mathrm{AE}$ & $7.1 \mathrm{a}$ & $6.4 \mathrm{~b}$ & $6.5 \mathrm{ab}$ & $1.3 b$ & $2.8 \mathrm{a}$ & $0.7 \mathrm{a}$ \\
\hline \multicolumn{7}{|l|}{ Water } \\
\hline Municipal & $6.6 \mathrm{a}$ & $6.7 \mathrm{a}$ & $6.6 \mathrm{a}$ & $1.3 \mathrm{a}$ & $1.3 \mathrm{a}$ & $0.4 \mathrm{a}$ \\
\hline Fertilizer & $6.6 \mathrm{a}$ & $6.7 \mathrm{a}$ & $6.5 \mathrm{a}$ & $1.3 \mathrm{a}$ & $1.4 \mathrm{a}$ & $0.4 \mathrm{a}$ \\
\hline \multicolumn{7}{|l|}{ Significance } \\
\hline Substrate & $* * *$ & $* * *$ & $* * *$ & $* * *$ & $* * *$ & $* * *$ \\
\hline Water & NS & NS & NS & NS & NS & NS \\
\hline Substrate and water & NS & NS & NS & NS & NS & NS \\
\hline
\end{tabular}

${ }^{\mathrm{z}}$ Mean separation of main effects within the same column followed by a different letter are significantly different by Tukey's test at $* P \leq 0.05, * * 0.01$, or $* * * 0.001$; NS $=$ non-significant 
Table 5 Effect of substrate and water interaction on tomato seedling SPAD readings 25 days after potting (DAP) and plant height 26 DAP in substrates substituted with different volumes of dewatered aquaculture effluent (AE)

\begin{tabular}{llllll}
\hline Water source $^{\mathrm{y}}$ & \multicolumn{2}{l}{ SPAD $(\mathrm{cm})^{\mathrm{z}}$} & & \multicolumn{2}{l}{ Plant height $(\mathrm{cm})$} \\
\cline { 2 - 3 } \cline { 5 - 6 } & Fertilizer $^{\mathrm{x}}$ & Municipal & & Fertilizer & Municipal \\
\hline Substrate $^{\mathrm{w}}$ & & & & \\
$0 \% \mathrm{AE}$ & $42.2 \mathrm{Ab}$ & $34.7 \mathrm{Bb}$ & & $19.2 \mathrm{Ab}$ & $15.1 \mathrm{Bb}$ \\
$5 \% \mathrm{AE}$ & $42.2 \mathrm{Bb}$ & $43.8 \mathrm{Aa}$ & & $23.1 \mathrm{Aa}$ & $22.2 \mathrm{Aa}$ \\
$10 \% \mathrm{AE}$ & $44.9 \mathrm{Aa}$ & $44.0 \mathrm{Aa}$ & & $19.7 \mathrm{Ab}$ & $20.3 \mathrm{Aa}$ \\
Significance & & & & \\
Substrate & $* * *$ & & $* * *$ & \\
Water & $* * *$ & & $* *$ & \\
Substrate and water & $* * *$ & & $* * *$ & \\
\hline
\end{tabular}

${ }^{\mathrm{z}}$ Leaf greenness of four recently mature leaves per plant was quantified with a chlorophyll meter (SPAD502; Minolta Camera Company, Ramsey, NJ)

${ }^{\mathrm{y}}$ Fertilizer $=20 \mathrm{~N}-4.4 \mathrm{P}-16.6 \mathrm{~K}$; Municipal $=$ Auburn, AL city water

${ }^{x}$ For each parameter values within column followed by different lower case letters are significantly different for pairwise comparisons of substrate within each level combination of water by Bonferroni adjusted $\alpha$-level $(P \leq 0.05)$

${ }^{w}$ For each parameter values within row followed by different upper case letters are significantly different for pairwise comparisons of water within each level combination of substrate by Bonferroni adjusted $\alpha$ level $(P \leq 0.05)$

${ }^{v} \mathrm{NS}=$ non-significant; $* P \leq 0.05 ; * * 0.01$, or $* * * 0.001$ based on two-way analyses of variance

Table 6 Effect of substrate and water interaction on tomato seedling leaf dry matter, stem dry matter, root dry matter and total dry matter $26 \mathrm{~d}$ after potting in substrates substituted with different volumes of dewatered aquaculture effluent (AE)

\begin{tabular}{|c|c|c|c|c|c|c|c|c|}
\hline \multirow[t]{2}{*}{ Water source ${ }^{\mathrm{y}}$} & \multicolumn{2}{|c|}{ Leaf dry matter (g) } & \multicolumn{2}{|c|}{ Stem dry matter $(\mathrm{g})$} & \multicolumn{2}{|c|}{ Root dry matter $(\mathrm{g})$} & \multicolumn{2}{|c|}{ Total dry matter $(\mathrm{g})^{\mathrm{z}}$} \\
\hline & Fertilizer $^{\mathrm{x}}$ & Municipal & Fertilizer & Municipal & Fertilizer & Municipal & Fertilizer & Municipal \\
\hline \multicolumn{9}{|l|}{ Substrate $^{\mathrm{w}}$} \\
\hline $0 \% \mathrm{AE}$ & $2.4 \mathrm{Ab}$ & $1.0 \mathrm{Bb}$ & $0.8 \mathrm{Ac}$ & $0.3 \mathrm{Bb}$ & $0.7 \mathrm{Ab}$ & $0.5 \mathrm{Bb}$ & $3.9 \mathrm{Ab}$ & $1.7 \mathrm{Bb}$ \\
\hline $5 \% \mathrm{AE}$ & 4.0 Aa & $3.5 \mathrm{Ba}$ & $1.4 \mathrm{Aa}$ & $1.3 \mathrm{Aa}$ & $1.0 \mathrm{Aa}$ & $0.8 \mathrm{Ba}$ & $6.3 \mathrm{Aa}$ & $5.5 \mathrm{Ba}$ \\
\hline $10 \% \mathrm{AE}$ & $3.9 \mathrm{Aa}$ & $3.7 \mathrm{Aa}$ & $1.2 \mathrm{Ab}$ & $1.2 \mathrm{Aa}$ & $1.0 \mathrm{Aa}$ & $1.0 \mathrm{Aa}$ & $6.0 \mathrm{Aa}$ & $5.8 \mathrm{Aa}$ \\
\hline \multicolumn{9}{|l|}{ Significance $^{\mathrm{v}}$} \\
\hline Substrate & $* * *$ & & $* * *$ & & $* * *$ & & $* * *$ & \\
\hline Water & $* * *$ & & $* * *$ & & $* *$ & & $* * *$ & \\
\hline Substrate and water & $* * *$ & & $* * *$ & & $*$ & & $* * *$ & \\
\hline
\end{tabular}

$\mathrm{z}$ Total dry matter includes cotyledons

${ }^{\mathrm{y}}$ Fertilizer $=20 \mathrm{~N}-4.4 \mathrm{P}-16.6 \mathrm{~K}$; Municipal $=$ Auburn, AL city water

${ }^{x}$ For each parameter values within column followed by different lower case letters are significantly different for pairwise comparisons of substrate within each level combination of water by Bonferroni adjusted $\alpha$-level $(P \leq 0.05)$

${ }^{\mathrm{w}}$ For each parameter values within row followed by different upper case letters are significantly different for pairwise comparisons of water within each level combination of substrate by Bonferroni adjusted $\alpha$-level $(P \leq 0.05)$

v NS = non-significant; $* P \leq 0.05$; $* * 0.01$; or $* * * 0.001$ based on two-way analyses of variance

Smaller particle size could have accelerated leaching of salts through physical breakdown of the AE substrates. In addition, the nutrient content of $\mathrm{AE}$, itself, may have also contributed to observed EC leachate values. Substrates did not exceed the threshold of $3.5 \mathrm{mS} \mathrm{cm}{ }^{-1}$ reported by Wright (1986) for healthy seedling growth.
A substrate and water interaction affected plant SPAD readings at 25 DAP (Table 5). Fertigating tomato plants grown in substrates with $0 \% \mathrm{AE}$ improved SPAD readings $21.6 \%$ compared to plants grown in the same substrate with municipal water. The commercial mix alone did not contain enough nutrients to sustain plant growth. 
Fertigating plants in $5 \%$ AE slightly decreased SPAD readings $3.7 \%$ compared to plants grown in the same substrate with municipal water. Water source did not affect SPAD reading of plants grown in $10 \%$ AE. Fertigating tomato plants grown in $10 \% \mathrm{AE}$ improved SPAD readings $6.4 \%$ compared to substrates with $\leq 5 \%$ AE. Commercial mix partially replaced $\mathrm{F} 3 \mathrm{~B}$ with $\geq 5 \% \mathrm{AE}$ and watered with municipal water improved SPAD readings $26.5 \%$ compared to plants grown in commercial mix alone.

There was a substrate and water interaction affecting plant height at 26 DAP (Table 5). Fertigating tomato plants grown in substrate with $0 \% \mathrm{AE}$ improved plant height $27.2 \%$ compared to plants grown in the same substrate and municipal water, indicating the potting mix alone did not have sufficient nutrients to maintain plant growth for a 26-day growing period. The combination of fertilizer and $5 \% \mathrm{AE}$ increased plant height $19 \%$ compared to the other substrates. Plant height improved approximately $41 \%$ using $\geq 5 \% \mathrm{AE}$ and municipal water compared to substrate with $0 \% \mathrm{AE}$ and municipal water.

There was a substrate and water interaction affecting LDM, SDM, RDM, and TDM at 26 DAP. Fertigating tomato plants grown in substrate with $0 \% \mathrm{AE}$ improved LDM, SDM, RDM, and TDM 140, 167, 40, and $129 \%$, respectively, compared to plants grown with the same substrate with municipal water (Table 6). Fertigating tomato plants grown in $5 \% \mathrm{AE}$ improved LDM, SDM, $\mathrm{RDM}$, and TDM $14,8,25$, and $15 \%$, respectively, compared to plants grown with $5 \% \mathrm{AE}$ and municipal water (Table 6). This suggests these potting mixtures, alone, were unable to supply the plants with sufficient amounts of nutrients, but fertigating these substrates improved plant growth. When substrate was partially replaced with $10 \%$ $\mathrm{AE}$ water source had no effect on plant growth indices, indicating this potting mix did have sufficient nutrients to maintain plant growth without the need for additional inorganic fertilizer.

Atiyeh et al. (2000) and Danaher et al. (2014) report substrates partially replaced with $<20 \%$ animal waste and supplied with all required mineral nutrients improved growth of tomato plants compared to traditional substrates. Their results correspond to the present experiment. But the present findings further advocate the potential benefit of $\mathrm{AE}$ alone as a nutrient source for tomato seedling production. In this experiment, different growth responses of tomato seedlings occurred when grown with specific combinations of amended F3B under fixed water regimes. Starter nutrients in the commercial mix were unable to supply sufficient amounts of nutrients for 26-day-old tomato plants requiring the addition of commercial fertilizer to improve plant growth. Although water source did make a difference in final growth indices for $5 \% \mathrm{AE}$, the difference between plants receiving fertigation or municipal was small. Water source had no impact on plant growth 26 DAP for plants grown in $10 \% \mathrm{AE}$, indicating this substrate could provide optimal physico-chemical parameters and sufficient nutrients for tomato plant growth without the need for fertigation.

The physical and chemical properties of different organic substrates are unique; therefore, each substrate should be characterized prior to partial replacement of container substrate to optimize plant growth. Atiyeh et al. (2001) and Subler et al. (1998) reported the incorporation of 5 and $10 \%$, respectively, vermicompost into container media improved growth of tomato transplants. Both Atiyeh et al. (2000) and Herrera et al. (2008) reported $30 \%$ replacement of commercial mix with vermicompost and municipal solid waste, respectively, enhanced tomato plant growth while greater amounts decreased plant growth. In studies by Lazcano et al. (2009) and Danaher et al. (2011), substitution of $\geq 50 \%$ container mix with alternative soilless substrates improved tomato transplant growth. Jahromi et al. (2012) reported commercial mix replaced with $\geq 60 \%$ compost outperformed the peat-based substrate even though EC concentrations exceeded $3.5 \mathrm{mS} \mathrm{cm}^{-1}$. Physical and chemical properties of organic wastes are non-uniform between animal species and consecutive batches at the same farm (García-Delgado et al. 2007; Naylor et al. 1999). Therefore, it is critical the horticulture producer evaluates the material before and after traditional substrates are partially replaced.

A simple economic analysis was done to determine the cost of obtaining the solid component created by the geotextile bag and polymer. It was based on an actual 5-month production period of Nile tilapia produced in the $100 \mathrm{~m}^{3}$ biofloc system at the E.W. Shell Fisheries Center, North Auburn Unit, in Auburn, AL. The cost of the $4.6 \times 3.1 \mathrm{~m}$, $10 \mathrm{oz}$, non-woven geotextile bag was $\$ 171$ and two, 19 liter buckets of liquifloc $1 \%$ chitosan ( $\$ 102$ per bucket) were required to flocculate the discharged effluent. The total cost of materials was $\$ 375$. A total of $1505 \mathrm{~kg}$ of tilapia diet (dry weight) was fed to the $100 \mathrm{~m}^{3}$ biofloc system over the five-month production period and approximately $284 \mathrm{~kg}$ of solids (dry weight), or $19 \%$ of the diet fed, was captured in the geotextile bag. This equates to $\$ 1.32$ per $\mathrm{kg}$ for dewatered solid matter (dry weight).

\section{Conclusions}

Increasing the proportion of dewatered aquaculture effluent to $10 \%$ container volume provided optimal physical and chemical properties for tomato plant growth, but different tomato growth responses occurred when grown with specific combinations of substrate and water source. In an 
integrated production system the dewatered effluent from the fish production system could be utilized as a resource for the production of tomato transplants without the need for additional inorganic fertilizer.

Acknowledgments The authors wish to thank the United Soybean Board for providing financial support through Grant \#1340-512-5254.

Authors' contributions J.D. carried out the experimentation and drafts of manuscripts. All authors read and approved the final manuscript.

\section{Compliance with ethical standards}

Conflict of interest The authors declare they have no competing interests.

Open Access This article is distributed under the terms of the Creative Commons Attribution 4.0 International License (http://crea tivecommons.org/licenses/by/4.0/), which permits unrestricted use, distribution, and reproduction in any medium, provided you give appropriate credit to the original author(s) and the source, provide a link to the Creative Commons license, and indicate if changes were made.

\section{References}

Adler PR, Summerfelt ST, Glenn DM, Takeda F (2003) Mechanistic approach to phytoremediation of water. Ecol Eng 20:251-264. doi:10.1016/s0925-8574(03)00044-2

Arenas M, Vavrina CS, Cornell JA, Hanlon EA, Hochmuth GJ (2002) Coir as an alternative to peat in media for tomato transplant production. HortScience 37:309-312. Retrieved from http:// hortsci.ashspublications.org

Atiyeh RM, Subler S, Edwards CA, Bachman G, Metzger JD, Shuster W (2000) Effects of vermicomposts and composts on plant growth in horticultural container media and soil. Pedobiologia 44:579-590. doi:10.1078/s0031-4056(04)70073-6

Atiyeh RM, Edwards CA, Subler S, Metzger JD (2001) Pig manure vermicompost as a component of a horticultural bedding plant medium: effects on physicochemical properties and plant growth. Bioresour Technol 78:11-20. doi:10.1016/s09608524(00)00172-3

Azim ME, Little DC (2008) The biofloc technology (BFT) in indoor tanks: water quality, biofloc composition, and growth and welfare of Nile tilapia (Oreochromis niloticus). Aquaculture 283:29-35. doi:10.1016/j.aquaculture.2008.06.036

Bachman GR, Metzger JD (2008) Growth of bedding plants in commercial potting substrate amended with vermicompost. Bioresour Technol 99:3155-3161. doi:10.1016/j.biortech.2007. 05.069

Bilderback TF, Fonteno WC, Johnson DR (1982) Physical properties of media composed of peanut hulls, pine bark and peat moss and their effects on azalea growth. J Am Soc Hortic Sci 107:522-525. Retrieved from http://journal.ashspublications.org

Boyd CE, Tucker CS (1998) Pond aquaculture water quality management. Kluwer Academic Publishers, Boston. doi:10. 1007/978-1-4615-5407-3

Ceglie FG, Elshafie H, Verrastro V, Tittarelli F (2011) Evaluation of olive pomace and green waste composts as peat substitutes for organic tomato seedling production. Compost Sci Util 19:293-300. doi:10.1080/1065657x.2011.10737011
Danaher JJ, Pantanella E, Rakocy JE, Shultz RC, Bailey DS (2011) Dewatering and composting aquaculture waste as a growing medium in the nursery production of tomato plants. Acta Hortic 891:223-229. doi:10.17660/actahortic.2011.891.26

Danaher JJ, Pickens JM, Sibley JL, Chappell JA, Hanson TR, Boyd CE (2014) Growth of tomato seedlings in commercial substrate amended with dewatered aquaculture effluent. Int J Veg Sci 20(4):340-353. doi:10.1080/19315260.2013.809622

Ebeling JM, Rishel KL, Sibrell PL (2005) Screening and evaluation of polymers as flocculation aids for the treatment of aquacultural effluents. Aquac Eng 33:235-249. doi:10.1016/j.aquaeng.2005. 02.001

Eudoxie GD, Alexander IA (2011) Spent mushroom substrate as a transplant media replacement for commercial peat in tomato seedling production. J Agric Sci 3:41-49. doi:10.5539/jas. v3n4p41

Evans MR, Gachukia M (2004) Fresh parboiled rice hulls serve as an alternative to perlite in greenhouse crop substrates. HortScience 39:232-235. Retrieved from http://hortsci.ashspublications.org/

García-Delgado M, Rodríguez-Cruz MS, Lorenzo LF, Arienzo M, Sánchez Martín MJ (2007) Seasonal and time variability of heavy metal content and of its chemical forms in sewage sludges from different wastewater treatment plants. Sci Total Environ 382:82-92. doi:10.1016/j.scitotenv.2007.04.009

Gruda N, Schnitzler GH (2004) Suitability of wood fiber substrates for production of vegetable transplants II. The effect of wood fiber substrates and their volume weights on the growth of tomato transplants. Sci Hortic 100:333-340. doi:10.1016/j. scienta.2003.09.004

Herrera F, Castillo JE, Chica AF, Lopez Bellido L (2008) Use of municipal solid waste compost (MSWC) as a growing medium in the nursery production of tomato plants. Bioresour Technol 99:287-296. doi:10.1016/j.biortech.2006.12.042

Hicklenton PR, Rodd V, Warman PR (2001) The effectiveness and consistency of source separated municipal solid waste and bark composts as components of container grown media. Sci Hortic 91:365-378. doi:10.1016/s0304-4238(01)00251-5

Jahromi MA, Aboutalebi A, Farahi MH (2012) Influence of different levels of garden compost (garden wastes and cow manure) on growth and stand establishment of tomato and cucumber in greenhouse condition. Afr J Biotechnol 11:9036-9039. doi:10. 5897/ajb11.4139

Kasmi A, Latigui A, Metai K, Sahli B, Dilem A (2012) Use of sewage sludge and fiber palm co-compost as components of substrates Lycopersicum esculentum and Cucumis melo cultivated in soilless crop. Am J Plant Physiol 7:92-103. doi:10.3923/ajpp. 2012.97.103

Kirsten WJ (1979) Automated methods for the determination of carbon, hydrogen, nitrogen, and sulfur alone in organic and inorganic materials. Anal Chem 51:1173-1179. doi:10.1021/ ac50044a019

Lazcano C, Arnold J, Tato A, Zaller JG, Domínguez J (2009) Compost and vermicompost as nursery pot components: effects on tomato plant growth and morphology. Span J Agr Res 7:944-951. doi:10.5424/sjar/2009074-1107

Levy JS, Taylor BR (2003) Effects of pulp mill solids and three composts on early growth of tomatoes. Bioresour Technol 89:297-305. doi:10.1016/s0960-8524(03)00065-8

Marble SC, Gilliam CH, Sibley JL, Fain GB, Torbert HA, Gallagher TV, Olive JW (2010) Evaluation of composted poultry litter as a substrate amendment for wholetree, clean chip residual, and pinebark for container grown woody nursery crops. J Environ Hortic 28:107-116. Retrieved from http://hriresearch.theknowl edgecenter.com/

Melgar-Ramirez R, Pascual-Alex MI (2010) Characterization and use of a vegetable waste vermicompost as an alternative component 
in substrates for horticultural seedbeds. Span J Agric Res 8:1174-1182. doi:10.5424/sjar/2010084-1407

Nair DNS (2006) Recycling aquacultural waste through horticultural greenhouse production as a resource recovery approach. Master's Thesis, Virginia Polytechnic Institute and State University. Retrieved from http://scholar.lib.vt.edu/

Naylor SJ, Moccia RD, Durant GM (1999) The chemical composition of settable solid fish waste (manure) from commercial rainbow trout farms in Ontario, Canada. N Am J Aquac 61:21-26. doi:10. 1577/1548-8454(1999)061<0021:tccoss $>2.0 . c 0 ; 2$

Palada MC, Cole WM, Crossman SMA (1999) Influence of effluents from intensive aquaculture and sludge on growth and yield of bell peppers. J Sustain Agric 14:85-103. doi:10.1300/ j064v14n04_08

Pantanella E, Danaher JJ, Rakocy JE, Shultz RC, Bailey DS (2011) Alternative media types for greenhouse seedling production of lettuce and basil. Acta Hortic 891:257-264. doi:10.17660/ actahortic.2011.891.31

Rakocy JE, Shultz RC, Bailey DS, Thoman ES (2003) Aquaponic production of tilapia and basil: comparing a batch and staggered cropping system. Acta Hortic 648:63-69. doi:10.17660/actahor tic. 2004.648 .8

Ribeiro HM, Romero AM, Pereira H, Borges P, Cabral F, Vasconcelos E (2007) Evaluation of a compost obtained from forestry wastes and solid phase of pig slurry as a substrate for seedlings production. Bioresour Technol 98:3294-3297. doi:10.1016/j. biortech.2006.07.002

Sims GK, Ellsworth TR, Mulvaney RL (1995) Microscale determination of inorganic nitrogen in water and soil extracts. Commun Soil Sci Plant Anal 26:303-316. doi:10.1080/ 00103629509369298

Subler S, Edwards CA, Metzger J (1998) Comparing vermicomposts and composts. BioCycle 39:63-66. Retrieved from http://www. nal.usda.gov/

Tyler HH, Warren SL, Bilderback TE, Fonteno WC (1993) Composted turkey litter: I. Effect on chemical and physical properties of a pine bark substrate. J Environ Hortic 11:131-136. Retrieved from http://hriresearch.theknowledgecenter.com

Wright RD (1986) The pour-through nutrient extraction procedure. HortScience 21:227-229. Retrieved from http://hortsci.ashspu blications.org

Yeager T, Bilderback T, Fare D, Gilliam C, Lea-Cox J, Niemiera A, Ruter J, Tilt K, Warren S, Whitwell T, Wright R (2007) Best management practices: guide for producing nursery crops, 2nd edn. Southern Nursery Association, Georgia. Retrieved from http://www.sna.org/ 